\title{
Impact of the 2004 tsunami on the Vulnerable Nicobar megapode Megapodius nicobariensis
}

K. S IV A K U M A R

\begin{abstract}
The small, isolated populations of the Nicobar megapode Megapodius nicobariensis, currently categorized as Vulnerable on the IUCN Red List, on the Nicobar islands in the Indian Ocean have declined by c. $70 \%$ since 1994. The 2004 tsunami is believed to be the major cause of this decline. The populations of megapodes on the islands of Megapode and Trax were wiped out by the tsunami. I estimate from a 2006 survey that 395-790 breeding pairs of the Nicobar megapode now survive on the coasts of the various islands compared to 2,318-4,056 pairs in 1994. The tsunami also adversely influenced nest-site selection and mound-nest ecology: $>50 \%$ of mounds were found closer to the shore in 2006 than in 1994, probably because of loss of suitable habitat, and they may become inundated with seawater during high tides. Most of the mound-nests found were constructed after the tsunami and were significantly smaller in volume than those present in 1994. Restoration of suitable habitat is critical for the long-term viability of the Nicobar megapode. However, post-tsunami impacts such as the creation of large-scale plantations in coastal areas, which are encroaching upon megapode habitat, may be severe. Because of the decline in numbers and habitat destruction and hunting the Nicobar megapode probably now qualifies for categorization as Endangered on the IUCN Red List.
\end{abstract}

Keywords Coastal biodiversity, habitat selection, isolated population, Megapodius nicobariensis, Nicobar islands, Nicobar megapode

\section{Introduction}

T solated populations of rare species may be disproportionately affected by both stochastic and deterministic factors such as hurricanes, fires, changes in habitat quality, inbreeding and genetic drift (Soulé, 1987; Burgman et al., 1993). To conserve such species there is a need to assess the impacts of such factors on the long-term survival of individual populations (Karen, 1998). An earthquake with a magnitude of 9.15, with its epicentre at $3.29^{\circ} \mathrm{N}$ and $95.94^{\circ} \mathrm{E}$ off the coast of Sumatra and with a focal depth of $30 \mathrm{~km}$, occurred on 26 December 2004 at 06.29. It triggered a tsunami that, amongst other effects, engulfed the entire

K. Sivakumar Wildlife Institute of India, P.O. Box. 18, Chandrabani, Dehradun-241001, India. E-mail ksivakumar@wii.gov.in

Received 3 June 2008. Revision requested 24 July 2008.

Accepted 2 October 2008. low-lying coastal forests of the Nicobar islands in the Bay of Bengal. The waters, which took several days to recede, devastated the people and wildlife of the Nicobar islands (Sankaran, 2005). This was the first recorded major natural catastrophe for the islands.

One species expected to have been adversely affected by the tsunami is the Nicobar megapode Megapodius nicobariensis. The megapodes utilize external sources of heat to incubate their eggs (Jones et al., 1995). The Nicobar megapode, a mound nesting bird, is endemic to the Nicobar Islands, separated from its nearest congener by a distance of $>1,500 \mathrm{~km}$ (Lister, 1911; Olson, 1980). There are two subspecies: $M$. $n$. nicobariensis on the Nancowry group of Islands north of the Sombrero channel and M. n. abbotti on the Great Nicobar group of islands south of the channel (Hume \& Marshall, 1878; Abdulali, 1964; Ali \& Ripley, 1983; Fig. 1). The species builds three types of mounds: A, built in open areas away from trees; $\mathrm{B}$, built against a living tree base; C, built on or around a dead log or stump (Dekker, 1992; Sankaran, 1995b; Sankaran \& Sivakumar, 1999; Sivakumar, 2000) and the sources of heat that create suitable incubation conditions vary with mound type, location and dimensions (Jones, 1987; Bowman et al., 1994; Palmer et al., 2000; Sinclair, 2002; Sinclair et al., 2002; Sivakumar \& Sankaran, 2003).

Historically the Nicobar megapode occurred on all Nicobar Islands (Hume, 1874; Kloss, 1903; Dekker, 1992; Sankaran, 1995a,b) except Car Nicobar (Butler, 1899), Chaura (Abdulali, 1967) and Bati Malv (Sankaran, 1995a). There are a few records of megapodes from the Andaman group of islands (Hume, 1874; Butler, 1899; Sewell, 1922) and from the Coco Islands further north (Kloss, 1903; Abdulali, 1964). None of the records from the Andaman group are of recent origin and the species is now believed to be absent there (Sankaran, 1995a,b). In 1994 the population of M. n. abbotti was estimated to be 3,400-6,000 and the number of active mounds 849 (Sankaran, 1995a). The population of breeding adults of $M$. n. nicobariensis was estimated to be $1,200-2,100$ and the number of active mounds c. 300 (Sankaran, 1995a). Habitat loss, hunting and egg collection are considered the major threats to the megapodes (Jones et al., 1995; Sivakumar \& Sankaran, 2003).

The 1994 survey of the Nicobar megapode (Sankaran, 1995b) was the only one made before the tsunami. I therefore took this as a baseline for comparison with the status and distribution of the megapode in 2006, one nesting season after the tsunami. Post-tsunami restoration, especially of coastal habitat, is still required in the Nicobar 


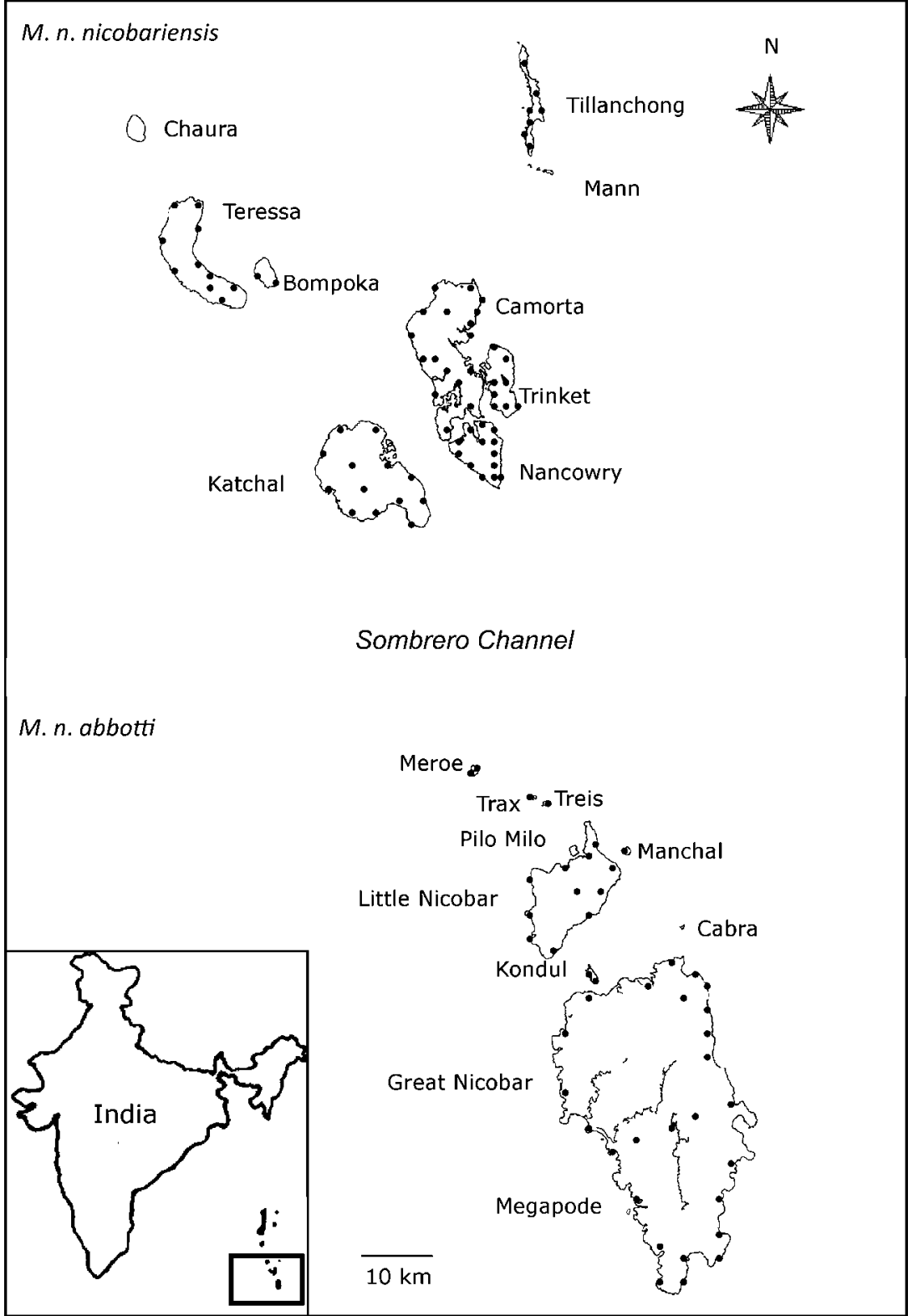

FIG. 1 Megapodius nicobariensis occurs as two subspecies: $M$. $n$. nicobariensis on the Nancowry island group north of the Sombrero channel and M. n. abbotti on the Great Nicobar island group south of the channel. The locations of the transects on each island are indicated as black circles. The inset indicates the location of the islands in the Bay of Bengal. islands. However, any ill-planned restoration could adversely affect the coastal-living megapodes. I therefore studied the post-tsunami conservation status of the coastal populations of the Nicobar megapode to provide information to support appropriate conservation action.

\section{Study area}

The Nicobar Islands can be subdivided into three subgroups based on ornithological affinities (Sankaran, 1995a). To the south lies the Great Nicobar group consisting of two islands $>100 \mathrm{~km}^{2}$, nine islets $>5 \mathrm{~km}^{2}$ in area, and a few rocks. Among them, Great Nicobar, Little Nicobar, Kondul and Pilo Milo are inhabited, and Meroe, Treis, Trax, Menchal, Megapode, Cabra and Pigeon are uninhabited. Fifty-eight $\mathrm{km}$ north of the Great Nicobar group is the
Nancowry group (Fig. 1) comprising three islands $>100 \mathrm{~km}^{2}$, two of 36 and $67 \mathrm{~km}^{2}$, three $<17 \mathrm{~km}^{2}$, two small islets and a few rocks. Except islets, all other islands of the Nancowry group are inhabited. The northernmost subgroup comprises Batti Malv and Car Nicobar, which are $88 \mathrm{~km}$ north of the Nancowry group. Batti Malv is uninhabited and Car Nicobar has a population of $>19,000$ people (Sankaran, 1995b).

Two groups of indigenous people inhabit the Nicobar Islands, along with settlers from the Indian mainland. The Shompen, who now number $<150$, are a semi-nomadic hunter-gather tribe who inhabit the forests of the central uplands. The Nicobarese, who have several settlements along the coast, constitute the largest tribal group of $>27,000$ people. The entire population of coastal-living Nicobarese, including settlers, were adversely affected by 
the tsunami and these people still need to be provided with new housing and, in most cases, alternative livelihoods.

\section{Methods}

This study was carried out during February-May 2006. Because the Nicobar megapode is shy and cryptic and therefore difficult to see in the forest whereas nesting mounds are stationary, inanimate and represent breeding signs, the easiest way to estimate and monitor a megapode population is by counting the number of active mounds (Dekker, 1992; Sankaran, 1995b; Sivakumar \& Sankaran, 2003). Surveys conducted in 1994 (Sankaran, 1995b) also utilized mound counts, thus facilitating a pre-tsunami comparison with the data collected in 2006.

The coastlines of the 15 islands on which the species was reported in 1994 were surveyed for mounds using a standardized survey protocol (Sankaran, 1995b). To estimate the total number of active mounds the coastline of each island was divided into suitable and unsuitable coastal habitat for mound building. Coastal habitat suitable for mound building has a sandy-loam substratum and littoral forests (Sivakumar, 2000). The extent of these two coastal habitat types was measured using satellite images (from 2006) and vegetation maps (Sankaran, 2005).

Variable width transects of 10-60o m were used to count all the mounds present within a surveyed area (the low lying coastal littoral forests are of varying width). Transect length and distance between transects was determined by island size but was uniform for an island. The mean length of a transect was $2 \mathrm{~km}$ but in some islands, the entire coast was surveyed because the total coastline was $<2 \mathrm{~km}$. The census was carried out with seven observers walking at $20-\mathrm{m}$ intervals parallel to the shore; for transects $>140 \mathrm{~m}$ wide we walked the transect more than once to cover the entire width. The interior forests of Great Nicobar, Little Nicobar, Camorta, Katchal and Teressa islands were surveyed, by seven observers, with $1-\mathrm{km}$ transects of $140 \mathrm{~m}$ width and $1 \mathrm{~km}$ long. The total number of active and abandoned mounds, mound size, green canopy cover over mound, and the distance between high tide mark and mounds were recorded.

Active mounds were identified by signs of recent digging by megapodes or by whether the soil was compact and hard, with vegetation growth (i.e. an abandoned mound) or loose and easily penetrable with a stick (i.e. an active mound; Sankaran, 1995b).

Because the distribution of mounds was not uniform (Sankaran, 1995b) the suitable and unsuitable segments of coastal areas were surveyed separately. A total of $328 \mathrm{~km}$ of coastal habitat was identified as suitable, of which $157.5 \mathrm{~km}$ were sampled in 80 transects ( 68 of $2 \mathrm{~km}, 10<2 \mathrm{~km}$, and two $>2 \mathrm{~km}$ ). Of the $358.8 \mathrm{~km}$ of unsuitable coastal habitat, $77.9 \mathrm{~km}$ were surveyed in 39 transects $(29$ of $2 \mathrm{~km}$, five
$>_{2} \mathrm{~km}$ and five $<_{2} \mathrm{~km}$ ). On most islands mound distribution was not uniform and therefore mound abundance, $D$, on an island was estimated using the following formula:

$$
D=\left(\frac{N}{S_{a}}\right) H_{a}
$$

where $N=$ total number of mounds found in $S_{\mathrm{a}}, a=$ habitat type (suitable or unsuitable), $S=$ total length of coastal area sampled in habitat $a$ and $H=$ total length of coastal area available for habitat $a$. Standard error of the mean number of mounds present per $\mathrm{km}$ of coast of an island was estimated when there were $>2$ transects on an island (Table 2).

Up to $20 \%$ of the megapodes are estimated to live in the interior forests of the islands (Dekker, 1992), which comprise $72 \%$ of the total area of the islands. Because of the difficulty in working in such forests survey intensity was lower, with 11 transects on Great Nicobar, four each on Little Nicobar and Camorta, three on Katchal, and two each on Teressa and Nancowry islands.

Basal circumference, height and diameter of mounds were measured. As mounds are uneven in shape and have a cone-like appearance, volume was calculated approximately using the equation for the volume of a cone: $1 / 3 \pi r^{2} h$, where $r$ is the radius and $h$ the height (Sivakumar \& Sankaran, 2003).

More than one pair of megapodes may use a mound. Sankaran (1995a) used two pairs per mound for the lower limit and 3.5 pairs as the upper limit but Sivakumar (2000) observed that a mean of 2.5 pairs used a mound. Most of the mounds that I observed were $<1$ year old (based on their size and the fact that most mounds were washed away by the tsunami) and too small to accommodate more than two pairs (Sivakumar \& Sankaran, 2003). Thus, for the population estimate I used one and two pairs as the lower and upper limits, respectively.

\section{Results}

In 2006 I found the Nicobar megapode on all but two islands (Trax and Megapode) from where it had been reported in 1994 (Sankaran, 1995a). Comparing the distribution of mounds from the shore inland there were significant differences between 1994 (Sankaran, 1995a) and 2006 (Wilcoxon signed ranks test, $Z=-2.934, \mathrm{P}<0.005 ; \mathrm{Fig} .2)$. In $2006>90 \%$ of mound nests were within $30 \mathrm{~m}$ of the shore and, of these, c. $16 \%$ of mounds were within $5 \mathrm{~m}$ of the shore.

I found significantly fewer active mound nests than reported in 1994 (paired sample $t$-test, $t=2.061, \mathrm{df}=14$, $\mathrm{P}<0.05$ ). Based on an estimated total of 394 active mounds (Table 1), I estimate that 394-788 breeding pairs of Nicobar 


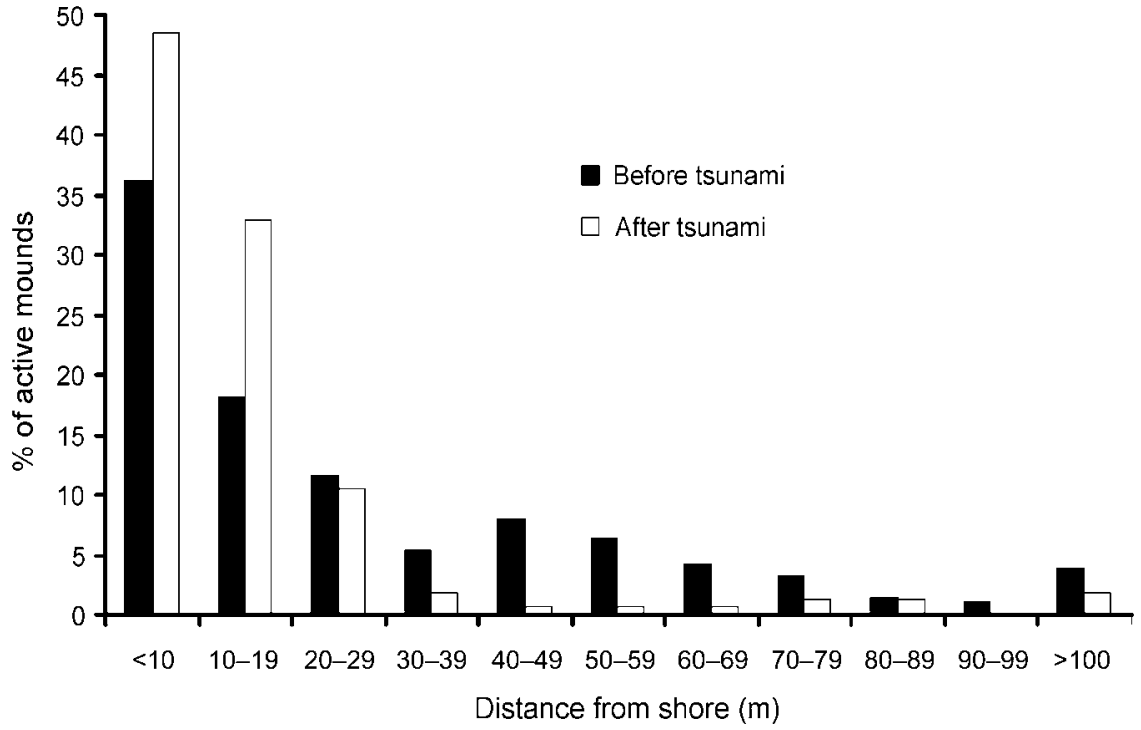

FIG. 2 Distance of active Nicobar megapode mound nests from the shore in 1994 (before the tsunami) and in 2006 (after the tsunami).

megapode now occur on the coastal habitat of the islands, which is $<70 \%$ of the numbers reported in 1994 .

Suitable coastal habitat for $M$. n. nicobariensis on the Nancowry island group (Fig. 1) shrank after the tsunami and only $37 \%$ of the coastal habitat is now available for mound building, with an estimated 97 active mounds and thus 97-194 breeding pairs. I did not find any active nest mounds in unsuitable coastal habitat (coconut plantations, mangroves, human habitation and cliffs). The islands of Tillanchang and Trinket, despite their relatively small size,

TABLE 1 Summary of the survey of the two subspecies of Nicobar megapode Megapodius nicobariensis carried out on 14 islands (Fig. 1) in 2006 in suitable and unsuitable habitat for mound building (see text for definitions), with total length of the coast of each island, length of coast surveyed and number of transects used, number of active mounds found, estimated total number of active mounds (extrapolated to the whole coast, see text for explanation), and estimated number of active mounds per km (with SE; suitable habitat only).

\begin{tabular}{|c|c|c|c|c|c|c|c|c|c|}
\hline \multirow[b]{2}{*}{ Island } & \multicolumn{5}{|c|}{ Suitable coastal habitat } & \multicolumn{4}{|c|}{ Unsuitable coastal habitat } \\
\hline & $\begin{array}{l}\text { Length } \\
(\mathrm{km})\end{array}$ & $\begin{array}{l}\text { Length surveyed, km } \\
\text { (no. of transects) }\end{array}$ & $\begin{array}{l}\text { Active } \\
\text { mounds }\end{array}$ & $\begin{array}{l}\text { Estimated } \\
\text { total active } \\
\text { mounds }\end{array}$ & $\begin{array}{l}\text { Active } \\
\text { mounds } \\
\pm \mathrm{SE}\left(\mathrm{km}^{-1}\right)\end{array}$ & $\begin{array}{l}\text { Length } \\
(\mathrm{km})\end{array}$ & $\begin{array}{l}\text { Length } \\
\text { surveyed, km } \\
\text { (no. of transects) }\end{array}$ & $\begin{array}{l}\text { Active } \\
\text { mounds }\end{array}$ & $\begin{array}{l}\text { Estimated } \\
\text { total } \\
\text { active } \\
\text { mounds }\end{array}$ \\
\hline \multicolumn{10}{|c|}{ M. n. abbotti (Great Nicobar island group) } \\
\hline Great Nicobar & 130 & $42.5(20)$ & 64 & 195.8 & $1.46 \pm 0.24$ & 83 & $12(6)$ & 1 & 7 \\
\hline Kondul & 1 & $1(1)$ & 1 & 1.0 & & 6.5 & $2(1)$ & 0 & 0 \\
\hline Little Nicobar & 55 & $17.5(9)$ & 25 & 78.6 & $1.46 \pm 0.39$ & 23 & $6(2)$ & 1 & 4 \\
\hline Megapode & 0 & 0 & 0 & 0 & & 0 & 0 & 0 & \\
\hline Menchal & 1 & $0.5(1)$ & 3 & 6.0 & & 2.3 & $1(1)$ & 0 & 0 \\
\hline Meroe & 2 & $2(1)$ & 2 & 2.0 & & 3.3 & $1(1)$ & 0 & 0 \\
\hline Pilo Milo & 0 & $1.5(1)$ & 0 & 0 & & 3 & $3(1)$ & 0 & 0 \\
\hline Trax & 0.1 & $0.1(1)$ & 0 & 0 & & 1.2 & $1.2(1)$ & 0 & 0 \\
\hline Treis & 2 & $2(1)$ & 3 & 3.0 & & 0.7 & $0.7(1)$ & 0 & 0 \\
\hline Subtotal & 191 & $67(35)$ & 98 & 286 & $155 \pm 0.67$ & 123 & $27(14)$ & 2 & 11 \\
\hline \multicolumn{10}{|c|}{ M. n. nicobariensis (Nancowry island group) } \\
\hline Nancowry & 17 & $16(8)$ & 7 & 7.4 & $0.44 \pm 0.20$ & 27.3 & $10(5)$ & 0 & 0 \\
\hline Katchal & 30 & $14(7)$ & 4 & 8.6 & $0.29 \pm 0.18$ & 48 & $12(6)$ & 0 & 0 \\
\hline Camorta & 35 & $21(11)$ & 4 & 6.7 & $0.23 \pm 0.10$ & 77.5 & $12(6)$ & 0 & 0 \\
\hline Tillanchang & 15 & $9(5)$ & 16 & 26.7 & $1.80 \pm 0.12$ & 27 & $6(2)$ & 0 & 0 \\
\hline Trinket & 15 & $11.5(6)$ & 20 & 26.1 & $1.75 \pm 0.51$ & 15 & $4(2)$ & 0 & 0 \\
\hline Teressa & 20 & $16(7)$ & 7 & 8.8 & $0.46 \pm 0.22$ & 33.3 & $6(3)$ & 0 & 0 \\
\hline Bampoka & 5 & $2(1)$ & 5 & 12.5 & & 7.8 & $1(1)$ & 0 & 0 \\
\hline Subtotal & 137 & $90.5(45)$ & 63 & 96.8 & $1.05 \pm 0.35$ & 236 & $51(25)$ & 0 & 0 \\
\hline Total & 328 & $157.5(80)$ & 161 & 383 & $1.32 \pm 0.39$ & 358.8 & 77.9 (39) & 2 & 11 \\
\hline
\end{tabular}


TABLE 2 Estimated total number of active mounds and breeding pairs of the two subspecies of Nicobar megapode in 1994 (Sankaran, $1995 \mathrm{~b}$ ) and 2006 (this study; number of active mounds is a sum of the estimated total number of active mounds in suitable and unsuitable habitat from Table 1).

\begin{tabular}{|c|c|c|c|c|}
\hline Island & $\begin{array}{l}\text { Estimated no. of } \\
\text { active mounds in } 2006\end{array}$ & $\begin{array}{l}\text { Estimated no. of } \\
\text { active mounds in } 1994\end{array}$ & $\begin{array}{l}\text { Estimated no. of breeding } \\
\text { pairs in } 2006 \text { (range) }\end{array}$ & $\begin{array}{l}\text { Estimated no. of breeding } \\
\text { pairs in } 1994 \text { (range) }\end{array}$ \\
\hline \multicolumn{5}{|c|}{ M. n. abbotti (Great Nicobar island group) } \\
\hline Great Nicobar & 203 & 515 & $203-406$ & $1,030-1,803$ \\
\hline Kondul & 1 & 11 & $1-2$ & $22-39$ \\
\hline Little Nicobar & 82 & 311 & $82-164$ & $622-1,089$ \\
\hline Megapode & 0 & 2 & 0 & $4-7$ \\
\hline Menchal & 6 & 2 & $6-12$ & $4-7$ \\
\hline Meroe & 2 & 1 & $2-4$ & $2-4$ \\
\hline Pilo Milo & 0 & 0 & 0 & 0 \\
\hline Trax & 0 & 3 & 0 & $6-11$ \\
\hline Treis & 3 & 4 & $3-6$ & $8-14$ \\
\hline Subtotal & 297 & 849 & $297-594$ & $1,698-2,972$ \\
\hline \multicolumn{5}{|c|}{ M. n. nicobariensis (Nancowry island group) } \\
\hline Nancowry & 7 & 60 & $7-14$ & $120-210$ \\
\hline Katchal & 9 & 69 & $9-18$ & $138-242$ \\
\hline Camorta & 7 & 20 & $7-14$ & $40-70$ \\
\hline Tillanchang & 27 & 10 & $27-54$ & $20-35$ \\
\hline Trinket & 26 & 8 & $26-56$ & $16-28$ \\
\hline Teressa & 9 & 119 & $9-18$ & $238-417$ \\
\hline Bampoka & 13 & 26 & $13-26$ & $52-91$ \\
\hline Subtotal & 98 & 312 & $98-196$ & $624-1,092$ \\
\hline Total & 394 & 1,161 & $395-790$ & $2,322-4,064$ \\
\hline
\end{tabular}

now hold nearly $50 \%$ of the population of this subspecies. The megapode populations on the larger islands of Camorta, Katchal, Teressa and Nancowry was estimated to be c. 63 breeding pairs, $88 \%$ less than estimated in 1994 (Table 2).

M. n. abbotti occurs on all of the islands of the southern Great Nicobar group (Fig. 1) except for Pilo Milo, Megapode and Trax where the megapode now appears to be extinct (megapodes were not found on Pilo Milo in 1994). Of the $314-\mathrm{km}$ coast $61 \%$ contains suitable habitat, and I found a total of 286 active mounds. In unsuitable coastal habitat I found 11 active mounds. I estimate that 297-594 breeding pairs occur on the coastal habitat of these islands. I found the largest population of this subspecies on Great Nicobar, with an estimated 203-406 breeding pairs. The second largest population is on Little Nicobar. These two islands are the largest in this group and provide breeding habitats for $96 \%$ of the total population of the subspecies.

There was a significance difference in the composition of mound types between 1994 and $2006\left(\chi^{2}=35.4, \mathrm{df}=2\right.$,

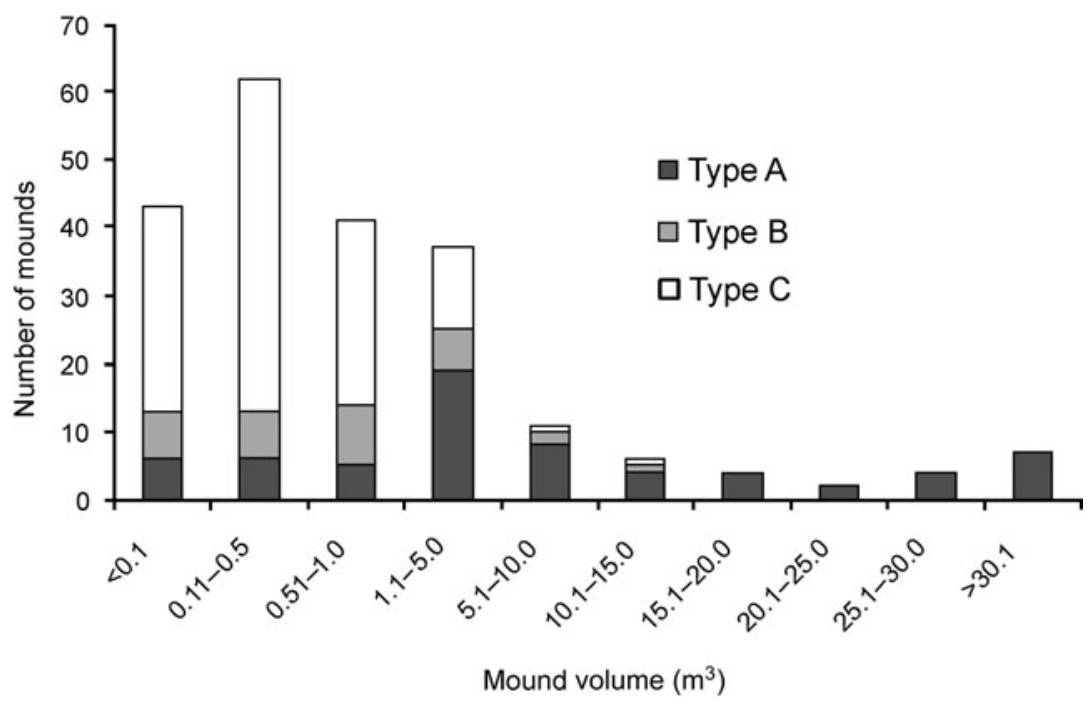

FIG. 3 Frequency distribution of mound nest volume of the three mound types (see text for details) of the Nicobar megapode. 


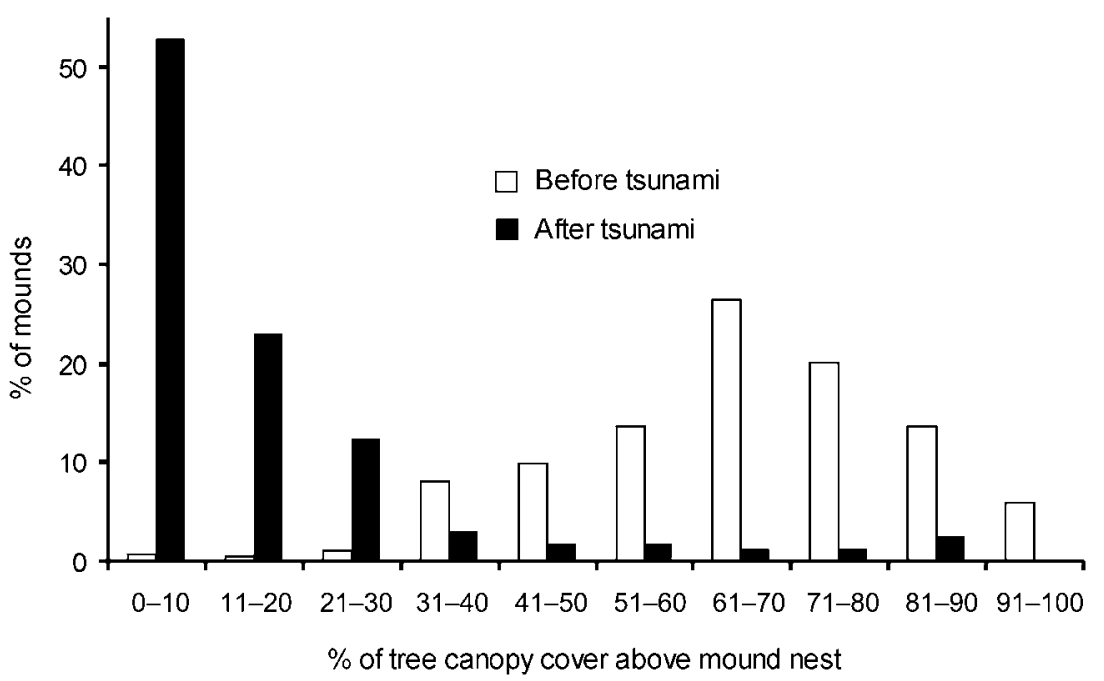

FIG. 4 Percentage of tree canopy cover above Nicobar megapode mound nests in 1994 (before the tsunami) and in 2006 (after the tsunami).
$\mathrm{P}<0.001$ ). In 2006 and 1994, respectively, 11 and $21 \%$ were Type A, 17 and $41 \%$ Type B, and 72 and $37 \%$ Type C. Mounds varied in volume $\left(0.01-71.45 \mathrm{~m}^{3}\right)$. Of the 217 observed mounds, the majority $(84 \%)$ were $<5 \mathrm{~m}^{3}$ and $67 \%$ were $<1 \mathrm{~m}^{3}$. Less than $6 \%$ of mounds were $>20 \mathrm{~m}^{3}$ and all of these were type A. Because most of the mounds were new and constructed after the tsunami the mean volume $(3.78 \pm$ SE $\left.0.62 \mathrm{~m}^{3}\right)$ was smaller than in $1994\left(6.34 \pm\right.$ SE $0.16 \mathrm{~m}^{3}$; Wilcoxon signed ranks test, $Z=-2.497, \mathrm{P}<0.05$ ). Type A mounds were generally of a greater range of volumes than Types B and C, which were generally small in size (Fig. 3). Green canopy cover above mounds was significantly less in 2006 than in 1994 (Wilcoxon signed ranks test, $Z=$ -2.090, P < 0.05; Fig. 4).

Of the 26 transects surveyed in the interior of the islands, mounds were found only on three transects, one on the southern tip of Great Nicobar, and two mounds from two different locations on Camorta. These mounds were not included in our population estimates.

\section{Discussion}

The major reason for the decline of the Nicobar megapode since 1994 appears to be the tsunami, which washed away both suitable habitat and nest mounds. In addition, the tsunami appears to have been the cause of the extirpation of the megapode on the islands of Megapode and Trax. Megapode was fully submerged for 3 weeks after the tsunami and the coastal areas of Trax were fully inundated. The Nicobar megapode appears preferentially to build mound nests in coastal areas because of the sandy-loam substratum there (Sivakumar, 2000; Sivakumar \& Sankaran, 2003). Compared to the previous survey (Sankaran, 1995b) the mounds were closer to the shore, possibly because the tsunami reduced the extent of suitable coastal habitat. These mounds, which were built near to the high tide mark, could be affected by abnormally high tides or waves. Maintaining mound temperature at a constant rate is important for successful egg incubation (Sivakumar \& Sankaran, 2003), and any influence of the nearby sea water on incubation temperature could adversely affect the hatching success of these mounds and lead to further population declines. I observed that human threats to the megapode, such as habitat degradation, hunting and egg collection, continue in the Nicobar islands.

I found the largest population of $M . n$. nicobariensis on Tillanchang despite its smaller size, and the population there is approximately the same size as in 1994. Tillanchang is the only Wildlife Sanctuary within the range of this subspecies, although I observed evidence of megapode hunting there. Because the intensity of the tsunami waves was diminished by the islands of Camorta, Katchal and Chaura before reaching Tillanchang, the impact of the tsunami was less on this island. However, the tsunami caused a drastic change in the number of mounds on all other islands (Table 2). As the earthquake occurred south of the Great Nicobar island group the tsunami waves arrived there first, and this may explain the $65 \%$ decrease in the population of M. n. abbotti on this island group compared to 1994.

The sources of heat that create suitable incubation conditions within a mound nest vary with mound type, location and size (Bowman et al., 1994; Palmer et al., 2000; Sinclair, 2002; Sinclair et al., 2002; Sivakumar \& Sankaran, 2003). Type A mounds are larger in size and normally used by $>3$ pairs (Sivakumar \& Sankaran, 2003) but the number of such mounds was greatly reduced by the tsunami. I saw a greater number of type $\mathrm{C}$ mounds, probably because of the availability of dead trees after the tsunami; type $\mathrm{C}$ mounds may become type A once the tree decomposes fully (Sivakumar \& Sankaran, 2003). Types B and C are normally smaller in size and accommodate fewer birds (Sivakumar \& Sankaran, 2003). The active mounds were mostly small in volume (Fig. 3), indicating that they were constructed after the tsunami. 
The temperature generated through fermentation of vegetative material inside a mound probably aids incubation (Sivakumar \& Sankaran, 2003) although ambient temperature may also have an influence (Jones, 1987; Sinclair, 2002; Sinclair et al., 2002). The reduced green canopy cover above mounds in 2006 compared to 1994 means that more direct sunlight is now falling on the mounds, which may therefore warm up more quickly (Sinclair, 2002; Sinclair et al., 2002). If temperatures become too hot this could have a detrimental effect on egg development.

The Nicobar megapode is included in Schedule I of the Indian Wildlife (Protection) Act, 1972 and is categorized as Vulnerable on the IUCN Red List (BirdLife International, 2008). However, as the population has decreased by c. $70 \%$ since 1994 and habitat destruction and hunting are still adversely affecting the species it probably qualifies for categorization as Endangered based on criteria (IUCN, 2001) Aracd, i.e. a reduction in population size (A), with an estimated reduction of $\geq 70 \%$ over the last 10 years (1) based on direct observation (a), an index of abundance (b) and a decline in extent of occurrence (c).

Island ecosystems are known for their resilience because of the possibilities for restoration by recolonization (Gunderson, 2000; Elmqvist et al., 2003). In this context, habitat restoration will be crucial for the long-term viability of the Nicobar megapode populations. There are currently two National Parks and two Wildlife Sanctuaries within the range of the megapode. Both National Parks are on Great Nicobar. Although these Parks offer some protection to $M$. $n$. abbotti, large extents of potential coastal habitat, especially along the west coast, are outside protected areas. The Wildlife Sanctuary of Megapode Island was completely submerged by the tsunami and no megapodes survived. Tillanchang Wildlife Sanctuary, which includes the whole of the island, is the only protected area that protects M. n. nicobariensis. Overall $<5 \%$ of the range of this subspecies is protected.

The tsunami washed away most of the planted as well as wild coastal coconut Cocos nucifera and areca nut Areca catechu palms and re-establishment of these plantations is important for the future survival of the islands' people. However, in the absence of appropriate planning the ongoing planting may encroach upon the coastal habitat of the Nicobar megapode.

Following the tsunami hunting pressure on the megapode has increased. Although the Nicobarese attach traditional cultural values to megapodes (the species is a symbol of love because of its monogamous breeding behaviour), scarcity of animal protein has forced them to hunt the species. A conservation education programme addressing this issue needs to be initiated. The two aboriginal tribes, the Nicobarese and Shompens, are exempt from the Indian Wildlife (Protection) Act, 1972. Considering the changing lifestyle of these two peoples
(Math et al., 2006) either this immunity needs to be reviewed or the tribes need to be involved in the conservation and management of both the megapode and the islands' protected areas.

The Andaman \& Nicobar Forest Department has already adopted some of the recommendations of this study, such as inter-departmental coordination in the re-establishment of coconut plantations so as to avoid plantation in prime megapode habitat. In addition, the Department has agreed, in principle, to initiate a programme to eradicate introduced cats and dogs, known to predate the megapode (Sivakumar, 2000), from the coastal areas of the Nicobar islands. The Department has also initiated a long-term monitoring programme of the habitat of the megapode.

\section{Acknowledgements}

I am grateful to Ravi Sankaran for his guidance and support, the Wildlife Institute of India and the Andaman \& Nicobar State Forest Department for funding and granting permission to carry out this survey, P.R. Sinha, V.B. Mathur, B.C. Choudhury, S.S. Choudhury, Madhava Trivedy, C.R. Mallick, Karthikeyan Vasudeven, J.C. Jayaraj, Ravichandran, Dharma Rao, S. Durai, Jona Phillips, Vishnudevan, Nagendra Kumar, Mahindra, Ravisundaram, Virendra Sharma R. Jayapal, R.W.R.J. Dekker, Darryl Jones, Guntram S.K. Mukerjee, V.B. Swarkar, A.J.T. Johnsingh, Asad Rahmani, Karthikeyan Vasudevan, B.S. Adhikari, K. Ramesh, Samuel Andrew, Jugulu Mehato, Chandrasekar Rao, S. Sivakumar, Koruma Rao, Damodhar Rao, Alkana, Rajan, Maianeus, Simos, James, Samuel and Rahul for their help, and Gillian Baker and two anonymous reviewers for valuable comments and suggestions that greatly improved this article.

\section{References}

A bdulali, H. (1964) The birds of the Andaman and Nicobar Islands. Journal of the Bombay Natural History Society, 63, 140-190.

A bdulali, H. (1967) The birds of the Nicobar islands with notes on some Andaman birds. Journal of the Bombay Natural History Society, 64, 140-190.

Ali, S. \& Ripley, S.D. (1983) Handbook of the Birds of India and Pakistan. Oxford University Press, Bombay, India.

BirdLife International (2008) Megapodius nicobariensis. In IUCN Red List of Threatened Species v. 2009.1. IUCN, Gland, Switzerland. Http://www.iucnredlist.org [accessed 31 August 2009].

Bowman, D.M.J.S., Woinarski, J.C.Z. \& Russel-Smith, J. (1994) Environmental relationships of orange-footed scrubfowl nests in the Northern Territory. Emu, 94, 181-185.

Burgman, M.A., Ferson, S. \& Akcakaya, H.R. (1993) Risk Assessment in Conservation Biology. Chapman and Hall, London, UK.

Butler, A.L. (1899) The birds of the Andaman and Nicobar Islands. Journal of the Bombay Natural History Society, 12, 386-403. 
Dek ker, R.W.R.J. (1992) Status and Breeding Biology of the Nicobar Megapode Megapodius nicobariensis abbotti on Great Nicobar, India. Report. National Museum of Natural History, Leiden, The Netherlands.

Elmqvist, T., Folke, C., Nyström, M., Peterson, G., Bengtsson, J., Walker, B. \& Norberg, J. (2003) Response diversity, ecosystem change, and resilience. Frontiers in Ecology and the Environment, 1, 488-494.

Gunderson, L.H. (2000) Ecological resilience-in theory and application. Annual Review of Ecology and Systematics, 31, 425-439.

Hume, A.O. (1874) Contributions to the ornithology of India. The islands of the Bay of Bengal. Stray Feathers, 2, 29-324.

Hume, A.O. \& Marshall, A.H.T. (1878) The Game Birds of India, Burma and Ceylon. Published by authors, Calcutta, India.

IUCN (2001) 2001 Categories and Criteria (version 3.1). IUCN, Gland, Switzerland. Http://www.iucnredlist.org/static/categories_criteria [accessed 28 October 2008].

Jones, D.N. (1987) Selection of incubation mound sites by the Australian brush-turkey Alectura lathami. Ibis, 130, 251-260.

Jones, D.N., Dekker, R.W.R.J. \& Roselaar, C.S. (1995) The Megapodes. Oxford University Press, Oxford, UK.

Karen, V.R. (1998) Evaluating the effects of habitat quality, connectivity, and catastrophes on a threatened species. Ecological Applications, 8, 854-865.

KLoss, C.B. (1903) In the Andaman and Nicobar Islands. John Murray, London, UK.

Lister, J.J. (1911) The distribution of the avian genus Megapodius in the Pacific Islands. Proceedings of the Zoological Society of London, $52,749-759$.

Math, S.B., Girimaji, S.C., Benegal, V., Kumar, G.S.U., Hamza, A. \& Nagaraja, D. (2006) Tsunami: psychosocial aspects of Andaman and Nicobar islands. Assessments and intervention in the early phase. International Review of Psychiatry, $18,233-239$

Olson, S.L. (1980) The significance of the distribution of the Megapodiidae. Emu, 80, 21-24.

Palmer, C., Christain, K.A. \& Fisher, A. (2000) Mound characteristics and behaviour of the orange-footed scrubfowl in the seasonal tropics of Australia. Emu, 100, 54-63.

SANKARAN, R. (1995a) The distribution, status and conservation of the Nicobar megapode Megapodius nicobariensis. Biological Conservation, 72, 17-25.

Sankaran, R. (1995b) The Nicobar Megapode and other Endemic Avifauna of the Nicobar Islands (Status and Conservation).
Technical Report 2. Salim Ali Centre for Ornithology and Natural History, Coimbatore, India.

Sankaran, R. (2005) The islands. In The Ground Beneath the Waves: Post-tsunami Impact Assessment of Wildlife and their Habitats in India, Volume 2 (eds R. Kaul \& V. Menon), pp. 1-103. Wildlife Trust of India, New Delhi, India.

Sankaran, R. \& Sivakumar, K. (1999) Preliminary results of an ongoing study of the Nicobar megapode Megapodius nicobariensis Blyth. Zoologische Verhandelingen, 327, 75-90.

SEWELL, S.R.B. (1922) A survey season in the Nicobar Islands on the R.I.M.S. 'Investigator', October, 1921 to March, 1922. Journal of the Bombay Natural History Society, 28, 970-989.

Sinclair, J.R. (2002) Selection of incubation mound sites by three sympatric megapodes in Papua New Guinea. Condor, 104, $395-406$.

Sinclair, J.R., O’Brien, T.G. \& Kinnaird, M.F. (2002) The selection of incubation sites by the Philippine megapode, Megapodius cumingii, in North Sulawesi, Indonesia. Emu, 102, 151-158.

Siva Kumar, K. (2000) A study on the breeding biology of the Nicobar megapode Megapodius nicobariensis. $\mathrm{PhD}$, Bharathiyar University, Coimbatore, India.

Siva Kumar, K. (2004) Introduced mammals in Andaman \& Nicobar Islands (India): a conservation perspective. Aliens, 17, 11.

Sivakumar, K. \& Sankaran, R. (2003) Incubation mound and hatching success of the Nicobar megapode Megapodius nicobariensis. Journal of the Bombay Natural History Society, 100, 375-387.

Soulé, M.E. (1987) Viable Populations for Conservation. Cambridge University Press, New York, USA.

\section{Biographical sketch}

K. SIVAKUMAR's research interests include avian ecology, island ecology, marine biology, invasive species and Antarctic wildlife. He has studied the ecology of the Nicobar megapode, red jungle fowl and olive ridley marine turtle, the mammals of Antarctica, and fishes of the Trans-Himalayas and the River Ganges. He has a particular interest in the avian fauna of island ecosystems and has been involved in the assessment of the conservation status of the threatened fauna of India. As well as being a member of the Wildlife Institute of India, he is the scientist in charge of the National Institute for Coastal and Marine Biodiversity. 